\title{
Gastric cancer in coalminers: final report
}

\author{
G M H SWAEN, COLletTe W H M AERDTS, J J M SLANGEN
}

From the Department of Occupational Medicine, University of Limburg, PO Box 616, 6200 MD Maastricht, The Netherlands

\begin{abstract}
A matched case-control study was conducted to investigate the risk of gastric cancer in coalminers in the southern part of Limburg, The Netherlands. All 683 male cases of gastric cancer were identified at the five pathology departments in the area, all histologically confirmed by a pathologist. For each case a control patient, free of gastric cancer, was selected from the same pathology department, matched on date of birth. Of the 1366 patients enrolled in the study, an occupational history was collected regarding previous employment in a Dutch coal mine. Of the patients with gastric cancer, $28 \%$ had been employed as underground workers in a coalmine compared with $25 \%$ of the control group. The odds ratio for underground coalmining and gastric cancer was $1 \cdot 15(95 \%$ confidence limits: $0 \cdot 89-1 \cdot 47)$. There was no evidence for the existence of a dose-response relation. It was concluded that the study did not provide support for the hypothesis that underground coalmining increases the risk of gastric cancer.
\end{abstract}

Coal is still of great importance to our society as a main source of energy. In 1983 there were 300000 miners employed in underground coal mining operations within the European Community. ${ }^{1}$ Various carcinogenic substances, such as benz(o)pyrene and benz(a)anthracene derivatives, have been identified in coal, ${ }^{2}$ and also inorganic carcinogens such as arsenic, cadmium, and chromium. ${ }^{3}$ It has also been postulated that dust in general is a risk factor for gastric cancer ${ }^{4}$; inhaled coal dust may reach the gastrointestinal tract through the pulmonary clearance system.

Some investigators have noted a higher incidence of gastric cancer in coalmining areas in $\mathrm{Utah}^{5}$ (refuted in a later study ${ }^{6}$ ) and in Britain. ${ }^{78}$ Retrospective cohort studies of coalminers have been carried out by Enterline, ${ }^{9}$ Rockette, ${ }^{10}$ and Atuhaire et $a^{11}$; Enterline reported a standardised mortality ratio of $\mathbf{2 7 5}$ for gastric cancer. In a $\mathbf{3 0}$ year follow up study of men in the Rhondda Fach mortality rates from gastric cancer were raised among underground miners. ${ }^{11}$ This was also true, however, for the nonminers in the study. Rockette followed up a group of about 23000 coalminers in the United States to investigate their mortality pattern ${ }^{10}$ and concluded that "an elevated gastric cancer risk is the third most consistent mortality finding for coalminers behind accidents and pneumoconiosis mortality." In a recent listing of carcinogenic agents and occupations, coalmining was regarded as an occupation associated with a raised risk of gastric cancer. ${ }^{12}$ It has been suggested that other factors such as socioeconomic status may be important in the relation between prolonged exposure to coal dust and gastric cancer. ${ }^{13-15}$ Meyer et al postulated that coalminers who do not have an impaired pulmonary clearance system as a result of smoking are at higher risk of gastric cancer than coalminers who do suffer from impaired pulmonary clearance. ${ }^{16}$ There is no evidence to support this hypothesis, however. Coalmining in the south east part of The Netherlands has been carried on since the twelfth century. In 1950 over 50000 workers were employed underground in the area of Limburg. At the end of the 1960s the coal mines were closed since they could not compete with foreign coalmining companies. Many different types of coal were mined, varying from anthracite to bituminous coals. Coal was mined from depths of 3000 feet and one of the mines was regarded as the largest two shaft coal mine in Europe.

Because of the availability of documentation about workers who had been employed in underground mining and the frequent occurrence of past occupational exposure to coal dust, we regarded the area as particularly suitable for conducting a casecontrol study to investigate the risk of gastric cancer in coalminers. A preliminary report of this study has been published. ${ }^{17}$

\section{Material and methods}

A total of 683 cases of gastric cancer, all histologically 
Table 1 Frequency distribution of main disease categories of the controls, selected from the pathology departments

\begin{tabular}{lrr}
\hline Disease category & No & $\%$ \\
\hline Circulatory diseases & 27 & 4 \\
Respiratory diseases & 56 & 8 \\
Digestive diseases & 144 & 21 \\
Urogenital diseases & 141 & 20 \\
Diseases of the skin and limbs & 103 & 15 \\
Diseases of internal secretion and & 18 & 3 \\
$\quad$ sensory organs & 40 & 6 \\
Other diseases & 154 & 23 \\
No abnormality & 683 & 100 \\
Total & & \\
\hline
\end{tabular}

confirmed, was collected at the five pathology departments located in the area. The histological confirmation took place between 1 January 1973 and 31 December 1983. An age matched control patient, free of the disease under investigation, was selected for each case at the same pathology department. It was decided to match on age (date of birth), because the a priori chance of being a coalminer is strongly related to age. The average difference between the dates of birth of the matched pairs was 62 days. The controls were randomly selected from the total patient population of the particular pathology department. Table 1 gives the diagnoses of the controls selected for the study. An underestimation of the true relative risk could have occurred if the control group contained many patients whose primary diagnosis for referral to the pathology department was pneumoconiosis. None of these patients, however, was selected as a control.

For all 1366 patients selected for the study, information was collected regarding their underground mining work. These data were available at the General Mining Fund, a central agency for all coalmining companies in The Netherlands. Since one of the tasks of the General Mining Fund was to keep records on all coalminers regarding their pension rights, an accurate registration existed for all workers who had ever worked underground in a Dutch coal mine. Every coalminer in The Netherlands was obligated to contribute to the General Mining Fund. The records of these contributions are still available for every former coalminer, since they form the basis for the pension benefits to which the contributors are entitled. The files of the General Mining Fund contain information about name, date of birth, address, date of employment, occupation, and by which coal mine the person was employed. These records were searched in a similar fashion for each of the 1366 patients enrolled in the study. In this search the date of birth was used as the personal identification. If the date of birth of a patient matched that of a file of the General Mining Fund the name and address were checked to see if the
Table 2 Frequency of an occupational history of underground coalmining work among 683 matched pairs of male cases of gastric cancer and controls

\begin{tabular}{llll}
\hline & \multicolumn{3}{l}{ Controls } \\
\cline { 2 - 4 } & $\begin{array}{l}\text { With history of } \begin{array}{l}\text { Without history } \\
\text { underground } \\
\text { mining }\end{array} \\
\text { of underground } \\
\text { mining }\end{array}$ & Total \\
\hline $\begin{array}{l}\text { Cases: } \\
\begin{array}{l}\text { With history of } \\
\text { underground mining }\end{array}\end{array}$ & 58 & 132 & 190 \\
$\begin{array}{l}\text { Without history of } \\
\text { underground mining }\end{array}$ & 115 & 378 & 493 \\
Total & 173 & 510 & 683 \\
\hline
\end{tabular}

match was correct. For this process it was importantr to estimate the accuracy of the dates of birth collected at the pathology departments. This was done for the first 500 patients by comparing the dates of birth of those recorded in the Population Registry. Of the $500 \mathrm{~g}$ patients, only one was recorded incorrectly. For the patients enrolled in the study, for whom a file existed $z$ at the General Mining Fund, a short occupationa history was recorded about employment in a Dutch coal mine.

The data collected in this study were analysed by means of a matched pair analysis as described 835 Schlesselman, ${ }^{18}$ which is similar to the metheod proposed by Mantel and Haenszel. ${ }^{19}$

\section{Results}

The files of the General Mining Fund were searched for all 1366 patients. Of the 683 cases of gastric can $\Rightarrow$ cer, 190 had a previous occupational history of under윽 ground coalmining. In the control group 173 patients had records showing an occupational history of un derground coalmining (see table 2). The odds ratio for underground coalmining was $1.15 \quad(95 \%$

Table 3 Occupational history of underground coalmining work among 683 cases of gastric cancer and 683 age matched controls by duration of employment in the Dutch coal mines

\begin{tabular}{|c|c|c|c|c|}
\hline \multirow{2}{*}{$\begin{array}{l}\text { Duration of underground } \\
\text { employment (years) }\end{array}$} & \multicolumn{2}{|c|}{$\begin{array}{l}\text { Cases } \\
\text { of gastric cancer }\end{array}$} & \multicolumn{2}{|c|}{$\begin{array}{l}\text { Controls, free } \\
\text { of gastric cancer }\end{array}$} \\
\hline & No & $\%$ & No & $\%$ \\
\hline $\begin{array}{l}<1 \\
1-5 \\
5-10 \\
10-20 \\
20-30 \\
30-40 \\
>40\end{array}$ & $\begin{array}{r}16 \\
30 \\
23 \\
30 \\
42 \\
45 \\
4\end{array}$ & $\begin{array}{r}8 \\
16 \\
12 \\
16 \\
22 \\
24 \\
2\end{array}$ & $\begin{array}{r}14 \\
29 \\
22 \\
29 \\
45 \\
30 \\
4\end{array}$ & $\begin{array}{r}8 \\
17 \\
13 \\
17 \\
26 \\
17 \\
2\end{array}$ \\
\hline Total & 190 & 100 & 173 & 100 \\
\hline
\end{tabular}


confidence limits $0 \cdot 89-1 \cdot 47$ ), calculated by applying the Mantel-Haenszel method for matched pairs, ${ }^{19}$ suggesting no statistically significant raised risk of gastric cancer among underground coalminers.

To study the existence of a dose-response relation a subanalysis was made by duration of underground coalmining work (table 3 ). There was no increase in risk with a longer duration of employment. The average duration of underground coalmining among the controls was 18.0 years and for the cases 18.8 years.

\section{Discussion}

Epidemiological studies investigating the risk of gastric cancer in coalminers have come up with contradictory results. In some studies an excess of gastric cancer was reported whereas in others no excess was found. The results of the study reported here do not indicate that coalminers are at higher risk from gastric cancer. In the study no adjustments were made for other factors that may be important in the development of gastric cancer. Social class is one of the factors that seems to play a part in the aetiology of gastric cancer, ${ }^{1320}$ low social class apparently being related to a higher risk for gastric cancer. Dutch coalminers before 1947 as a group earned less than the average employee. Of the coalminers included in this study, $79 \%$ had coalmining experience before 1947 . Thus if social class had a confounding effect on our findings it would most likely have resulted in a bias away from the null hypothesis, resulting in a positive outcome even though in reality there may not be an excess risk of gastric cancer among coalminers. It is also postulated that diet may be important in the aetiology of gastric cancer. ${ }^{21}$ The risks are small, however, and these factors are unlikely to have had a confounding effect in the present study.

We thank the staffs of the pathology departments of Brunssum, Heerlen, Kerkrade, and Maastricht en Sittard for taking part in the study and also the "AZL Heerlen" manager of the General Mining Fund for helpful instructions during the study. The study was financially supported by The Queen Wilhelmina Fund in Amsterdam.

\section{References}

1 Coal Eurostatistics Monthly 1984;1:1-6.

2 Tye R, Horton AW, Rapien I. Benzo(ap)pyrene and other aromatic hydrocarbons extractable from bituminous coal. Am Ind Hyg Assoc J 1966;27:25-31.

3 Braunstein HM, Copenhaver ED, Pfuderer HA. Environmental health and control aspects of coal conversion: an information overview. Vol 1. Oak Ridge TN: Oak Ridge National Laboratory, 1977.

4 Fox AJ, Goldblatt P, Kinlen LA. A study of the mortality of Cornish tin miners. Br J Ind Med 1981;38:378-80.

5 Matolo NM, Klauber MR, Gorishek WM, et al. High incidence of gastric carcinoma in a coal mining region. Cancer 1972;27:733-7.

6 Klauber MR, Lyon JL. Gastric cancer in a coal mining region. Cancer 1978;41:2355-8.

7 Ashley BJB. Environmental factors in the aetiology of gastric cancer. Br J Prev Soc Med 1969;23:187-9.

8 Stocks P. On the death rates from cancer of the stomach and respiratory diseases in 1949-53 among coalminers and other male residents in countries of England and Wales. Br J Cancer 1962;16:592-8.

9 Enterline PE. Mortality rates among coal miners. Am J Public Health 1964;54:758-68.

10 Rockette HE. Cause-specific mortality of coal miners. $J$ Occup Med 1977;19:795-801.

11 Atuhaire LK, Campbell MJ, Cochrane AL, Jones M, Moore F. Mortality of men in the Rhondda Fach 1950-80. Br J Ind Med 1985;42:741-5.

12 Decoufle P. Occupational. In: Schottenfeld D, Fraumeni JF, eds. Cancer epidemiology and prevention. London: WB Saunders Company, 1982.

13 International Union against Cancer. Stomach cancer. Geneva: IUAC, 1978. (Technical report No 34.)

14 Ames RG. Gastric cancer in coal miners: some hypotheses for investigation. J Soc Occup Med 1982;32:73-81.

15 Creagan ET, Hoover RN, Fraumeni JF. Mortality from stomach cancer in coal mining regions. Arch Environ Health 1974;28:28-30.

16 Meyer MB, Luh GD, Sotelo JM, et al. Hypothesis: the role of the lung in stomach carcinogenesis. Am Rev Respir Dis 1980;121:887-92.

17 Swaen GMH, Aerdts CWHM, Sturmans F, Slangen JJM, Knipschild P. Gastric cancer in coal miners: a case-control study in a coal mining area. Br J Ind Med 1985;42:627-30.

18 Schlesselman JJ. Case-control studies, design conduct, analysis. Oxford: Oxford University Press, 1982:207-13.

19 Fleis JL. Statistical methods for rates and proportions. New York: John Wiley and Sons, 1981:115.

20 Higginson $\mathrm{J}$. Etiological factors in gastro-intestinal cancer in man. JNCI 1966;37:527-45.

21 Bjelke E. Epidemiologic studies of cancer of the stomach, colon and rectum: with special emphasis on the role of diet. Scand $J$ Gastroenterol 1974;9, suppl 31:42-53. 